\title{
Hubungan kadar kolesterol total dengan tekanan darah pada guru di SMP 1 \& 2 Eben Haezar dan SMA Eben Haezar Manado
}

\author{
${ }^{1}$ Sitti H. Naue \\ ${ }^{2}$ Vanda Doda \\ ${ }^{2}$ Herlina Wungouw
}

\author{
${ }^{1}$ Kandidat Skripsi Fakultas Kedokteran Universitas Sam Ratulangi Manado \\ ${ }^{2}$ Bagian Fisiologi Fakultas Kedokteran Universitas Sam Ratulangi Manado \\ Email: Sittihairunnisa@yahoo.co.id
}

\begin{abstract}
Hypertension is the third cause of death, coming after stroke and tuberculosis, which encompasses 6,7\% mortality ages in Indonesia. This study aims to identify the correlation between total cholesterol level and blood pressure on teachers. This study is a cross-sectional design. A total of 83 Teachers participation in this study by using total sampling method. This study found that the correlation between total cholesterol level and systolic blood pressure is not significant $(\mathrm{r}=-0,070)$. The same thing was done to test the correlation between total cholesterol level and diastolic blood pressure. It was found that the $r$ between both variables is $-0,090$, while the determination coefficient $\left(r^{2}\right)$ is 0,008 . The average of systolic and diastolic blood pressure on teachers is $118 \mathrm{mmHg}$ and $77 \mathrm{mmHg}$. The average of total cholesterol level on teachers is $176 \mathrm{mg} / \mathrm{dl}$. This study conclude that there is no correlation between total cholesterol level and blood pressure on teachers. However it is worth to evaluate the relationship between cholesterol and blood pressure using random time cholesterol.
\end{abstract}

Keywords: total cholesterol level, blood pressure, teachers

\begin{abstract}
Abstrak: Hipertensi merupakan penyebab kematian nomor tiga setelah stroke dan tuberkulosis, yakni mencapai 6,7\% kematian pada semua umur di Indonesia. Penelitian ini bertujuan untuk mengetahui hubungan antara kadar kolesterol total dengan tekanan darah pada guru. Penelitian ini menggunakan metode cross-sectional. 83 guru berpartisipasi dalam penelitian ini, pengambilan sampel menggunakan total sampling Setelah dilakukan uji statistika, ditemukan bahwa tidak signifikan hubungan antara kolestrol total dan tekanan darah Sistolik di mana $(r=-0,070)$. Hal yang sama dilakukan untuk menguji hubungan antara kolesterol total dengan tekanan darah diastolik, didapatkan bahwa koefisien korelasi (r) antara kolestrol total dengan tekanan darah diastolik sebesar -0,090, sementara koefisien determinasi $\left(\mathrm{r}^{2}\right)$ sebesar 0,008 . Setelah dilakukan uji signifikansi, kedua variabel mempunyai hubungan negatif dan tidak signifikan pada taraf uji $5 \%$. Rata-rata tekanan darah sistolik dan diastolik pada guru di SMP dan SMA Eben Haezar Manado adalah $118 \mathrm{mmHg}$ dan 77 mmHg. Rata-rata kadar kolesterol total adalah $176 \mathrm{mg} / \mathrm{dl}$. Pada penelitian ini tidak terdapat hubungan yang signifikan antara kadar kolesterol total dan tekanan darah pada guru. Bagaimanapun, untuk mengevaluasi hubungan antara kadar kolesterol total dengan tekanan darah bisa menggunakan kadar kolesterol sewaktu.
\end{abstract}

Kata kunci: kadar kolesterol total, tekanan darah, guru

Hipertensi adalah salah satu penyakit yang sering melanda di dunia dan faktor risiko penting untuk penyakit jantung. ${ }^{1}$ Pada tahun 2008 diperkirakan sebanyak 17,3 juta kematian disebabkan oleh penyakit kardiovaskuler. Lebih dari 3 juta kematian 
tersebut terjadi sebelum usia 60 tahun. Menurut Depkes, kematian "dini" yang disebabkan oleh penyakit jantung terjadi berkisar sebesar $4 \%$ di negara berpenghasilan tinggi dan $42 \%$ terjadi di negara berpenghasilan rendah. ${ }^{2}$ Menurut WHO (World Health Organization), pada tahun 2013 diperkirakan negara terbanyak penderita hipertensi adalah Afrika (46\% orang dewasa) dan yang paling rendah adalah Amerika (35\% orang dewasa). ${ }^{3}$ Di berbagai negara di Asia, prevalensi hipertensi bervariasi, berkisar antara 15 $35 \%$. Angka tersebut diperkirakan akan terus meningkat setiap tahunnya. ${ }^{4}$ Data Riskesdas (Riset Kesehatan Dasar) pada tahun 2007 menyebutkan prevalensi hipertensi di Indonesia berkisar 30\% dengan insiden komplikasi penyakit kardiovaskular lebih banyak pada perempuan $(52 \%)$ dibandingkan laki-laki $(48 \%){ }^{5}$ Prevalensi hipertensi di Sulawesi Utara yang diperoleh melalui kuisioner terdiagnosis tenaga kesehatan adalah $15 \%$, sedangkan melalui minum obat $15,2 \%$ dan melalui pengukuran adalah $27,1 \%{ }^{6}$

Dalam tubuh manusia, kolesterol dapat berasal dari makanan sehari-hari yang digolongkan sebagai kolesterol eksogenik dan yang disintesis di dalam tubuh sebagai kolesterol endogenik. ${ }^{7}$ Di Indonesia, prevalensi hiperkolesterolemia pada usia 25-34 tahun adalah 9,3\% sedangkan pada usia 55-64 tahun sebesar 15,5\%. Angka kejadian hiperkolesterolemia pada penelitian MONICA I (Multinational Monitoring of Trends Deter minants in Cardiovascular Diseases) sebesar $13.4 \%$ untuk wanita dan 11,4\% untuk pria. Pada MONICA II didapatkan meningkat menjadi $16,2 \%$ untuk wanita dan $14 \%$ pria. Wanita menjadi kelompok paling banyak menderita masalah ini yakni 14,5 persen atau hampir dua kali lipat kelompok lakilakI. Laporan WHO menyebutkan bahwa pada tahun 2002, tercatat sebanyak 4,4 juta kematian PJK adalah akibat hiperkolesterol atau sebesar $7,9 \%$ dari jumlah total kematian di usia muda. ${ }^{8-9}$ Peningkatan kolesterol serum yang terjadi, terutama mencerminkan peningkatan kolesterol-
LDL. Low Density Lipoprotein (LDL) merupakan lipoprotein yang memiliki kandungan kolesterol tertinggi dibandingkan lipoprotein lainnya. Penyebab utama hiperlipidemia adalah obesitas, asupan alkohol yang berlebihan, diabetes melitus, hipotiroidisme, dan sindrom nefrotik. Klasifikasi WHO membagi kasus menjadi tipe I hingga V. Sayangnya, klasifikasi ini tidak menunjukan penyebab hiperlipidemia (primer maupun sekunder). Salah satu konsekuensi hiperlipidemia yang paling penting (terutama tipe IIa) adalah peningkatan kolesterol serum, yang terutama mencerminkan kolesterol lipoprotein serum densitas rendah (LDLC), merupakan faktor predisposisi terjadinya ateroma. ${ }^{10}$ Tujuan dari penelitian ini adalah untuk mengetahui hubungan kadar kolesterol total dengan tekanan darah pada guru di SMP 1 \& 2 Eben Haezar Manado dan SMA Eben Haezar Manado.

\section{METODE PENELITIAN}

Penelitian ini menggunakan metode analitik cross-sectional untuk meneliti bagaimanakah hubungan kadar kolesterol total dengan tekanan darah pada guru di SMP 1 \& 2 Eben Haezar Manado dan SMA Eben Haezar Manado. Populasi yang diambil yaitu, seluruh guru di SMP $1 \& 2$ Eben Haezar Manado dan SMA Eben Haezar Manado yang berjumlah 83 responden. Pengambilan sampel menggunakan teknik total sampling. Penelitian ini dilakukan dengan memberikan lembar persetujuan, kuisioner dan pengukuran kadar kolesterol total serta tekanan darah. Variabel bebas dalam penelitian ini adalah kolesterol sedangkan variabel terikat adalah tekanan darah. Uji korelasi product moment digunakan untuk mengetahui hubungan antara kolesterol dan tekanan darah pada guru.

\section{HASIL PENELITIAN}

Pada Tabel 1 dapat dilihat bahwa mayoritas responden berusia $\leq 40$ tahun sebanyak $56 \%$ dan responden berjenis kelamin perempuan, sebanyak $69,3 \%$. 
Tabel 1. Karakteristik Responden

\begin{tabular}{lcc}
$\quad$ Karakteristik & Jumlah (n) & ( \% ) \\
Usia Responden & & \\
a. $\leq 40$ Tahun & 42 & 56 \\
b. $>$ 40 Tahun & 33 & 44 \\
Jenis Kelamin & & \\
a. Laki-laki & 23 & 30.7 \\
b. Perempuan & 52 & 69.3 \\
Total & 75 & 100 \\
\hline
\end{tabular}

Tabel 2 menunjukan bahwa sebanyak $7,1 \%$ responden dalam kategori usia yang tidak berisiko memiliki kadar kolesterol dalam kategori berisiko. Sedangkan usia di atas 40 tahun didapatkan sebanyak $27,3 \%$ responden dalam kategori berisiko.

Tabel 2. Kadar Kolesterol Total Terhadap Usia

\begin{tabular}{lccc}
\hline Usia & \multicolumn{3}{c}{ Kolesterol Total } \\
& & $\begin{array}{c}\text { Tidak } \\
\text { Berisiko } \\
(<200)\end{array}$ & $\begin{array}{c}\text { Berisiko } \\
(\geq 200)\end{array}$ \\
\hline a. $\leq 40$ Tahun & $\mathrm{n}$ & 39 & 3 \\
& $(\%)$ & $(92.9)$ & $(7.1)$ \\
b. $>$ 40 Tahun & $\mathrm{n}$ & 24 & 9 \\
& $(\%)$ & $(72.7)$ & $(27.3)$ \\
\hline
\end{tabular}

Tabel 3 menunjukkan bahwa semua responden berjenis kelamin laki-laki memiliki kadar kolesterol total dalam kategori tidak berisiko, sedangkan responden berjenis kelamin perempuan sebanyak $23 \%$ berada dalam kategori berisiko.

Pada Tabel 4 dapat dilihat usia tidak berisiko sebanyak sebanyak 21,4 responden memiliki tekanan darah sistolik diatas 120 mmHg dan sebanyak 9,5 responden memiliki tekanan darah diastolik diatas 80 mmHg. Sedangkan pada tabel dibawah juga dapat dilihat pada usia berisiko sebanyak $42,4 \%$ responden yang memiliki tekanan darah sistolik diatas $120 \mathrm{mmHg}$ dan sebanyak $27,3 \%$ responden yang memiliki tekanan darah diastolik diatas 80 $\mathrm{mmHg}$.
Tabel 3. Kadar Kolesterol Total Terhadap Jenis Kelamin

\begin{tabular}{lccc}
\hline \multicolumn{1}{c}{ Variabel } & \multicolumn{2}{c}{ Kolesterol Total } \\
& & $\begin{array}{c}\text { Tidak } \\
\text { Berisiko } \\
(<200)\end{array}$ & $\begin{array}{c}\text { Berisiko } \\
(\geq 200)\end{array}$ \\
\hline Jenis & & & \\
Kelamin & & & \\
a. Laki-laki & $\mathrm{n}$ & 23 & 0 \\
b. Perempuan & $(\%)$ & $(100)$ & \\
& $\mathrm{n}$ & 40 & 12 \\
& $(\%)$ & $(77)$ & $(23)$ \\
\hline
\end{tabular}

Tabel 4. Tekanan Darah Terhadap Usia

\begin{tabular}{cccc}
\hline \multirow{2}{*}{$\begin{array}{c}\text { Tekanan } \\
\text { Darah }\end{array}$} & & \multicolumn{2}{c}{ Usidak } \\
Berisiko & Berisiko \\
a. Sistolik & & & \\
$\quad$ Tidak & & & 19 \\
Berisiko & $\mathrm{n}$ & 33 & 19 \\
$(\leq 120)$ & $(\%)$ & $(78.6)$ & $(57.6)$ \\
Berisiko & $\mathrm{n}$ & 9 & 14 \\
$(>120)$ & $(\%)$ & $(21.4)$ & $(42.4)$ \\
\hline b. Diastolik & & & \\
Tidak & $\mathrm{n}$ & 38 & 24 \\
Berisiko & & & \\
$(\leq 80)$ & $(\%)$ & $(90.5)$ & $(72.7)$ \\
Berisiko & $\mathrm{n}$ & 4 & 9 \\
$(>80)$ & $(\%)$ & $(9.5)$ & $(27.3)$ \\
\hline
\end{tabular}

Tabel 5 memperlihatkan dari responden yang berjenis kelamin laki-laki sebanyak 47,8 \% responden memiliki tekanan darah sistolik diatas $120 \mathrm{mmHg}$. Sedangkan pada responden yang berjenis kelamin perempuan sebanyak 23,1 \% responden yang memiliki tekanan darah sistolik di atas $120 \mathrm{mmHg}$. Sedangkan responden berjenis kelamin laki-laki sebanyak $13 \%$ responden memiliki tekanan darah diastolik cukup tinggi. Sedangkan responden perempuan sebanyak $19,2 \%$ responden yang memiliki tekanan darah diastolik cukup tinggi.

Tabel 6 menunjukkan bahwa koefisien korelasi (r) diperoleh sebesar -0,070. Setelah dilakukan uji signifikansi, koefisien korelasi sebesar $-0,070$ adalah tidak signifikan hubungan kolesterol total dengan 
tekanan darah sistolik dengan taraf signifikansi 5\%. Ini dapat disimpulkan bahwa hubungan antara kolesterol total dengan tekanan darah sistolik bersifat negatif dan tidak signifikan.

Tabel 5. Tekanan Darah Terhadap Jenis Kelamin

\begin{tabular}{cccc}
\hline Tekanan & & \multicolumn{2}{c}{ Jenis kelamin } \\
Darah & & Laki-laki & Perempuan \\
a. Sistolik & & & \\
Tidak & $\mathrm{n}$ & 12 & 40 \\
Berisiko & & & \\
$(\leq 120)$ & $(\%)$ & $(52.2)$ & $(76.9)$ \\
Berisiko & $\mathrm{n}$ & 11 & 12 \\
$(>120)$ & $(\%)$ & $(47.8)$ & $(23.1)$ \\
\hline b. Diastolik & & & \\
Tidak & $\mathrm{n}$ & 20 & 42 \\
Berisiko & $\mathrm{n}$ & \\
$(\leq 80)$ & $(\%)$ & $(87)$ & $(80.8)$ \\
Berisiko & $\mathrm{n}$ & 3 & 10 \\
$(>80)$ & $(\%)$ & $(13)$ & $(19.2)$ \\
\hline
\end{tabular}

Tabel 6. Matriks Korelasi Kadar Kolesterol Total dengan Tekanan Darah Sistolik

\begin{tabular}{lll}
\hline & $\begin{array}{l}\text { Tekanan } \\
\text { Sistolik }\end{array}$ & Darah \\
\hline Sistolik & 1,000 & \\
Kolesterol & $-0,070$ & \\
Total &, 275 & \\
P Value & \\
\hline
\end{tabular}

Tabel 7 menunjukkan bahwa koefisien korelasi antara kolesterol total dengan tekanan darah diastolik diperoleh (r) sebesar -0,090, sedangkan koefisien determinasi $\left(r^{2}\right)$ diperoleh sebesar 0,008.

Tabel 7. Matriks Korelasi Kadar Kolesterol Total dengan Tekanan Darah Diastolik

\begin{tabular}{lll}
\hline & $\begin{array}{l}\text { Tekanan } \\
\text { Diastolik }\end{array}$ & Darah \\
\hline Diastolik & 1,000 & \\
Kolesterol Total & $-0,090$ & \\
P Value &, 221 & \\
\hline
\end{tabular}

Setelah dilakukan uji signifikansi, ternyata kedua variabel mempunyai hubungan negatif dan tidak signifikan pada taraf uji $5 \%$. Dengan demikian, hipotesis yang diajukan tidak teruji keberlakuannya secara empirik.

\section{BAHASAN}

\section{Umur Terhadap Kadar Kolesterol Total dengan Tekanan Darah}

Hasil penelitian yang dilakukan, seperti pada tabel 2 didapatkan bahwa umur diatas 40 tahun memiliki kadar kolesterol dalam kategori berisiko dibanding umur dibawah 40 tahun.

Hasil penelitian ini sesuai dengan penelitian yang dilakukan oleh Listiana dan Purbosari, menunjukan bahwa terdapat hubungan yang signifikan antara usia dan kolesterol total. Hal ini menunjukan bahwa usia dapat mempengaruhi kadar kolesterol total seseorang. Pada usia semakin tua kadar kolesterol totalnya relative lebih tinggi dari pada kadar kolesterol total pada usia muda, hal ini dikarenakan makin tua seseorang aktifitas reseptor LDL mungkin makin berkurang. Sel reseptor ini berfungsi sebagai hemostasis pengatur peredaran kolesteron dalam darah dan benyak terdapat dalam hati, kelenjar gonad dan kelenjar adrenal. Apa bila sel reseptor ini terganggu maka kolesterol akan meningkat dalam sirkulasi darah. ${ }^{11}$

Pada Tabel 4 menunjukan bahwa peningkatan tekanan darah sistolik maupun diastolik pada usia yang berisiko lebih tinggi dibandingkan usia yang tidak berisiko.

Pada umumnya penderita hipertensi adalah orang-orang berusia diatas 40 tahun, namun saat ini tidak menutup kemungkinan diderita oleh orang usia muda. Sebagian besar hipertensi primer terjadi pada usia 25-45 tahun dan pada $20 \%$ terjadi dibawah usia 20 tahun dan diatas 50 tahun. Hal ini disebabkan karena orang pada usia produktif jarang memperhatikan kesehatan, seperti pola makan dan pola hidup yang kurang sehat seperti merokok. ${ }^{12}$

\section{Jenis Kelamin Terhadap Kadar Kolesterol Total dengan Tekanan Darah}

Hasil penelitian didapatkan bahwa, terjadi peningkatan kadar kolesterol total 
dalam darah pada responden perempuan, sedangkan responden laki-laki tidak didapatkan peningkatan kadar kolesterol dalam darah.

Hasil ini sejalan dengan penelitian yang dilakukan oleh Khairani diperoleh profil lipid menurut jenis kelamin menunjukan bahwa wanita mempunyai kadar kolesterol total $\geq 240 \mathrm{mg} / \mathrm{dl}$, LDL kolesterol $\geq 160 \mathrm{mg} / \mathrm{dl}$ lebih besar dibanding pria, sedangkan pria mempunyai kadar HDL Kolesterol <40 mg/dl lebih besar dibandingkan wanita. ${ }^{13}$

Hasil penelitian yang dilakukan oleh Robiyyatu dan Karso menunjukan hasil yang berbeda, responden yang berjenis kelamin laki-laki hampir seluruhnya mengalami kolesterol di ambang batas atas. $^{14}$

Tekanan darah sistolik mengalami peningkatan yang cukup tinggi pada responden berjenis kelamin laki-laki. Sedangkan responden yang berjenis kelamin perempuan mengalami peningkatan tekanan darah diastolik cukup tinggi dibandingkan responden berjenis kelamin laki-laki.

Hal yang serupa juga ditemukan oleh Novitaningtyas, terdapat $43,7 \%$ responden yang berjenis kelamin perempuan lebih tinggi menderita hipertensi daripada lakilaki. ${ }^{15}$

\section{Hubungan Kadar Kolesterol Total dengan Tekanan Darah}

Mengacu pada hasil-hasil analisis data sekaligus pengujian hipotesis, diketahui bahwa hipotesis yang diajukan tidak teruji keberlakuannya secara empirik. Artinya bahwa kadar kolestrol total dalam darah berhubungan tidak nyata dan negatif dengan tekanan darah pada guru SMP 1 \& 2 Eben Haezar Manado dan SMA Eben Haezar Manado, maka dapat dijelaskan lebih lanjut bahwa ada variabel atau faktor pengganggu (ektraneus) atau faktor perancu yang menyebabkan hubungan Koletrol Total dengan Tekanan darah tidak bermakna bahkan negatif.

Penelitian ini sejalan dengan penelitian yang dilakukan oleh Lingga yang menurutnya, tidak semua penderita hiperkolesterolemia menderita hipertensi dan tidak semua penderita hipertensi menderita hiperkolesterolemia, tetapi level kolesterol darah yang cenderung tinggi mendorong peningkatan tekanan darah. ${ }^{16}$ Orang yang paling berisiko memiliki kadar kolesterol tinggi adalah mereka yang menerapkan pola makan yang mengandung lemak jenuh tinggi seperti yang terdapat pada ikan, mentega, keju, dan krim akan meningkatkan kadar kolesterol Low Density Lipoprotein (LDL) dalam darah. ${ }^{16}$

Pada penelitian yang dilakukan di Dusun Jetis Bantul Yogyakarta oleh Lestari, tidak terdapat hubungan antara kadar kolesterol dengan tekanan darah pra lansia hipertensi. ${ }^{17}$ Interpretasi nilai korelasi menunjukkan bahwa tingkat hubungan sangat rendah dengan hubungan yang berlawanan arah (negatif), sehingga semakin besar nilai suatu variabel maka semakin kecil nilai variabelnya. ${ }^{17}$

Pada penelitian yang dilakukan oleh Margarita dkk yang dilakukan pada tahun 2013 menemukan hasil yang berbeda, yakni terdapat hubungan yang signifikan antara kadar kolesterol total dengan tekanan darah pada orang dewasa. ${ }^{18} \mathrm{Hal}$ yang serupa juga ditemukan oleh Tyas dan Catur yang melakukan penelitian pada tahun 2015, didapatkan hubungan yang bermakna secara statistik antara kadar kolesterol total dalam darah dengan tekanan darah sistolik dan diastolik. ${ }^{19}$

Hubungan antara serum kolesterol dan tekanan darah juga diteliti di Oslo, Nowegia diantara sampel laki-laki yang berusia 20-49. Hasil penelitian menunjukkan korelasi lemah antara tekanan darah dan kolesterol. ${ }^{20}$ Penelitian di London dengan subjek penelitian sekitar 12,000 orang menunjukkan hubungan yang bermakna antara serum kolesterol dan

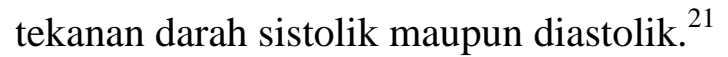

Makanan merupakan penyebab penting risiko terbentuknya kadar kolesterol yang tinggi pada darah. Tingginya kadar kolesterol dapat meningkatkan kemungkinan terjadinya tekanan darah yang tinggi. Timbunan kolesterol di dalam 
darah akan mengakibatkan penebalan dinding arteri yang disebabkan oleh plak kolesterol. Ketika dinding-dinding pada pembuluh darah menjadi tebal dan kaku karena tumpukan kolesterol, maka saluran arteri kehilangan kelenturannya dan menjadi kaku. Akibatnya, pembuluh darah tidak dapat mengembang secara elastis saat jantung memompa darah melalui pembuluh darah dan darah didorong dengan kuat untuk dapat melalui pembuluh darah yang sempit tersebut, sehingga menyebabkan kenaikan tekanan darah. ${ }^{22}$

Keterbatasan penelitian ini adalah yang pertama, peneliti belum bisa mengendalikan faktor-faktor yang bisa mempengaruhi kadar kolesterol tidak dikontrol misalnya, mengkonsumsi obat penurun tekanan darah dan obat penurun kolesterol dalam darah, pola didup (makanan, rokok, alkohol, aktivitas fisik). Kedua, pengukuran kadar kolesterol total sesaat belum lazim digunakan dalam penelitian, namun menurut penelitian yang dilakukan di Denmark yang melibatkan lebih dari 300 individu dan sudah dilakukan sejak 2009, menyatakan bahwa pasien tidak perlu berpuasa untuk mengecek kadar kolesterol. Berdasarkan hasil penelitian yang dilakukan tersebut, di temukan bahwa tidak ada perbedaan yang signifikan antara kadar kolesterol pasien yang berpuasa dengan pasien yang tidak berpuasa. $^{23}$ Menurut penelitian yang di publikasi oleh Harvard Health Publication Journal, bahwa makan atau tidak puasa sebelum melakukan pengukuran kadar kolesterol tidak akan mempengaruhi hasil kadar kolesterol total. ${ }^{24}$ Dan yang ketiga, peneliti juga belum dapat menampilkan jenis dari kolesterol seperti: Low Density Lipoprotein (LDL), High Density Lipoprotein (HDL) dan Trigliserida yang mengalami peningkatan karena disini pemeriksaan yang dilakukan menggunakan pengukuran kadar kolesterol total pada responden.

\section{SIMPULAN}

Rata-rata tekanan darah sistolik dan diastolik pada guru di SMP dan SMA Eben
Haezar Manado adalah $118 \mathrm{mmHg}$ dan 77 mmHg. Rata-rata kadar kolesterol total adalah $176 \mathrm{mg} / \mathrm{dl}$.Berdasarkan hasil uji statistik yang telah dilakukan, dapat disimpulkan bahwa tidak terdapat hubungan antara kolesterol dan tekanan darah pada guru di SMP 1 \& 2 Eben Haezar Manado dan SMA Eben Haezar Manado.

\section{SARAN}

Bagi para guru yang bekerja di SMP 1 \& 2 Eben Haezar Manado dan SMA Eben Haezar Manado pada saat mengajar di dalam kelas sebaiknya bergerak aktif. Para guru juga diharapkan agar dapat mengatur pola hidup dengan baik, diantaranya adalah dengan mengurangi asupan makanan yang mengandung tinggi kolesterol dan juga berolahraga secara teratur. Bagi petugas kesehatan perlu diingatkan kembali untuk melakukan penyuluhan kepada masyarakat agar mereka dapat memulai pola hidup yang sehat.

\section{DAFTAR PUSTAKA}

1. Madhur MS. 2011. Hypertension. Medscape. [Diakses 2016 Sept 20]. Diakses Dari: http://emedicine.medscape.com/article/ 241381-overview

2. Depkes RI. 2009. Hipertensi Penyebab Kematian Nomor Tiga. [Internet]. [Diakses 2016 Sept 20].

3. World Health Organization. World Health Day 2013: Measure Your blood pressure, reduce your risk. 2013. Media Center. [Diakses 2016 Sept 21].

4. Singh RB, Suh IL, Singh VP, Chaithiraphan, Laothavorn P, Sy RG, dkk. Hypertension and stroke in Asia: prevalence, control and strategies in developing countries for prevention. J Hum Hyper [internet]. 2000; 14 (10/11): 749-63 [Di akses 2016 Nov 24]. [Diakses dari: http://www.nature.com/jhh/journal/v14/ n10/abs/100105 7a.html]

5. Prasetyaningrum YI. Hipertensi Bukan Untuk Ditakuti. Jakarta: Fmedia; 2014.

6. Dedullah RF. Hubungan antara faktor risiko hipertensi dengan kejadian hipertensi pada masyarakat di kelurahan motoboi kecil kecamatan kotamobagu selatan kota kotamobagu. 2015. 
7. Roslizawaty, Rusli, Rani S, Suraidawati, Armansyah T, Zuhrawaty, dkk. Pengaruh Ekstrak Etanol Sarang Semut (Myrmecodia sp.) Lokal Terhadap Kadar Kolesterol Total Tikus Putih (Rattus norvegicus) Jantan Hiperkolesterolemia. Jurnal Veterinaria. 2015;9(1):37-9.

8. Brata HW. Hubungan Pola Makan, Obesitas, Keteraturan Berolahraga \& Kebiasaan Merokok Dengan Kejadian Hiperkolesterolemia. Unismus digital library. 2010.

9. Linawati, Sienny. 2011. Perbandingan Marker Inflamasi Antara Sindroma Koroner Akut dan Non Sindroma Koroner Akut. [internet]. [Diakses 2016 Nov 24]

10.Price SA, Wilson LM. Patofisiologi Konsep Klinis Proses-Proses Penyakit, edisi 6. Jakarta : Penerbit Buku Kedokteran EGC; 2006. (1).h.580-1.

11.Listiana L, Purbosari T Y. Kadar kolesterol total pada usia 25-60 tahun. Health Science. Vol 5, No 1. 2010. Hal 36-40.

12.Dhianningtyas, Yunita \& Hendrati, Luca Y. Risiko obesitas, kebiasaan merokok, dan konsumsi garam terhadap kejadian hipertensi pada usia produktif. The Indonesian journal of Publik Health. Vol 2, No 3. 2006.

13. Hernawati N, Citrakesumasari, Virani D. 2009. Uji sensitivitas skor riskesdas coronary heart disease terhadap rasio LDL/HDL pada pasien rawat jalan rsud kabupaten pangkep. Makassar: Universitas Hasanuddin.

14. Robiyyatun S, Karso I. 2015. Hubungan hipertensi dengan kadar kolesterol total dalam darah pada usia 36-45 tahun di desa jabon yang berkunjung di puskesmas jabon kabupaten jombang. Jombang: Stikes Pemkab Jombang.

15. Novitaningtyas T. 2014. Hubungan karakteristik (umur, jenis kelamin, tingkat pendidikan) dan aktivitas fisik dengan tekanan darah pada lansia di kelurahan makamhaji kecamatan kartasura kabupaten sukoharjo. [Skripsi].

16.Lingga L. 2012. Bebas Hipertensi Tanpa Obat. Jakarta: Agro Media Pustaka.
17.Lestari TW. 2015. Hubungan kadar kolesterol dengan tekanan darah pada pra lansia hipertensi di posyandu lansia dusun jetis bantul yogyakarta. [Skripsi]. Yogyakarta: Sekolah Tinggi Ilmu Kesehatan 'Aisyiyah

18. Margarita Y, Princen, Andi, Rumawas ME, Khidarsa VB, Sutrisna B. Kadar kolesterol total dan tekanan darah orang dewasa indonesia. Jurnal Kesehatan Masyarakat Nasional. 2013;8(2):79-84.

19. Tyas RTK, Catur A. 2015. Hubungan kadar kolesterol dengan tekanan darah pada lansia di posyandu lansia dharma bakti kelurahan genting-kalianak kota surabaya. [Skripsi]. Surabaya: STIKES Hang tuah.

20.Hjerman I, Helgeland A, Holme I, Larsen P. The association between blood pressure and serum cholesterol in healthy men: the Oslo study. J Epidemiol Comm Health. 1978; 32: 117-23.

21.Pincherle G, Robinson D. Mean blood pressure and its relation to other factors determined at a routine executive health examination.J Chronic Dis. 1974; 27: $245-60$.

22.Harefa K, Manurung K, Irawati J. 2009. Hubungan kadar kolesterol dengan tekanan darah pada pasien hipertensi diruang penyakit dalam rsud swadanatarutung. [Skripsi]. Medan: Universitas Sari Mutiara.

23. Nordesgaard B G, Langsted A, Mora S, Kolovou G, Baum H, Bruckert E, dkk. 2016. Fasting is not routinely required for determination of a lipid profile: clinical and laboratory implications including flagging at desirable concentration cut-points- a joint consensus statement from the European qaterosclerosis society and European. European Heart Journal. [Internet]. [Diakses pada tanggal 2016 Des 2]

24. President and fellows of Harvard Medical School. Which cholesterol test should you get?. Harvard Health Publications [Internet]. Diperbarui pada 2009 Jun. [Diakses pada tanggal 2016 Des 2]. 